\title{
PENGARUH MODIFIED AUDIT OPINION TERHADAP BORROWING CASH FLOW DI LQ45 SELAMA TAHUN 2010 - 2015
}

\author{
Windasari Rachmawati ${ }^{1}$ \\ Abdul Manan² \\ $\frac{\text { windasarirachmawati78@gmail.com }}{\text { 1 }}$ \\ Universitas Semarang
}

Diterima: Mei 2019, Disetujui: Juni 2019, Dipublikasikan: Juli 2019

\begin{abstract}
This study examines and analyzes the economic consequences of modified audit opinion on borrowing cash flow. This study uses a panel data model. Modified audit opinion (MAO) in this study is an audit opinion other than fair opinion without standard form exception, that is, unqualified opinion with an explanatory paragraph (unqualified opinion with explanatory paragraph), reasonable with an exception (qualified opinion), not reasonable (adverse opinion), and does not provide an opinion (disclaimer opinion). Population and research samples are companies that are members of $L Q 45$, except banking companies, insurance companies and other financial companies.

The results of this study were taken from 45 samples of companies registered in LQ45 then selected again based on the criteria of non-banking and financial companies. The result is a research sample of 40 research sample companies. After testing with SPSS using the classic assumption test and multiple regression with model 1 and model 2, the results for the Modified audit opinion have no effect on Borrowing cash flow with the control variables of investment cash flow, growth, size and leverage. Researchers see that the regression results from the control variable there is one variable that affects the cash flow Borrowing when testing model 1, namely the growth or sales increase variable.
\end{abstract}

Keywords: modified audit opinion, borrowing cash flow

\begin{abstract}
ABSTRAK
Penelitian ini menguji dan menganalisis konsekuensi ekonomis dari modified audit opinion terhadap borrowing cash flow. Penelitian ini menggunakan model data panel. Modified audit opinion (MAO) dalam penelitian ini adalah opini audit selain opini wajar tanpa pengecualian bentuk baku, yaitu opini wajar tanpa pengecualian dengan paragraf penjelasan (unqualified opinion with explanatory paragraph), wajar dengan pengecualian (qualified opinion), tidak
\end{abstract}


wajar (adverse opinion), dan tidak memberikan pendapat (disclaimer opinion).Populasi dan sampel penelitian adalah perusahaan - perusahaan yang tergabung dalam LQ 45, kecuali perusahaan perbankan, perusahaan asuransi dan perusahaan keuangan lainnya.

Hasil dari penelitian ini di ambil dari 45 sampel perusahaan yang terdaftar di LQ45 kemudian di pilih kembali berdasarkan kriteria perusahaan non perbankan dan keuangan. Hasilnya sampel penelitian berjumlah 40 perusahaan sampel penelitian. Setelah dilakukan pengujian dengan SPSS menggunakan uji asumsi klasik dan regresi berganda dengan dibuat model 1 dan model 2, maka di peroleh hasil untuk Modified audit opinion tidak berpengaruh terhadap Borrowing cash flow dengan variabel kontrol investment cash flow, growth, size dan leverage. Peneliti melihat bahwa hasil regresi dari variabel kontrol ada satu variabel yang berpengaruh terhadap Borrowing cash flow pada saat pengujian model 1 yaitu variabel growth atau peningkatan penjualan.

Kata kunci: modified audit opinion, borrowing cash flow

\section{PENDAHULUAN}

Auditor memiliki peranan penting dalam menilai apakah laporan keuangan perusahaan telah disajikan secara wajar. Hal ini terlihat dari kasus-kasus yang terjadi pada perusahaan besar, seperti kasus Enron. Dalam kasus Enron, auditor yang tidak independen menyebabkan perusahaan tersebut bangkrut. Hal ini terjadi karena auditor yang mengaudit Enron juga merupakan konsultan perusahaan sehingga laporan audit yang dihasilkan tidak berkualitas.

Motivasi penelitian ini berdasarkan pada topik mengenai tanggung jawab auditor dalam mengungkapkan tentang masalah going concern tentang opini audit yang dikeluarkan oleh auditor. Laporan keuangan adalah kinerja perusahaan dalam mendapatkan trust atau kepercayaan dari investor ataupun perusahaan itu sendiri dalam borrowing cash flow.

Tentunya hal ini menunjukkan bahwa informasi yang tercantum dalam laporan keuangan tidaksesuai dengan kondisi keuangan perusahaan yang sebenarnya sehingga merugikan para investor. Dalam membuat laporan audit, auditor akan memberikan opini terhadap suatu laporan keuangan. Opini tersebut menunjukkan apakah laporan keuangan perusahaan telah disajikan secara wajar. Terdapat lima jenis opini audit, yaitu unqualified opinion, unqualified opinion 
with explanatory paragraph, qualified opinion, adverse opinion, dan disclaimer opinion. Unqualified audit opinion merupakan opini yang diberikan auditor dimana laporan keuangan telah disajikan secara wajar dan telah sesuai dengan standar akuntansi yang berlaku. Sedangkan yang dimaksud modified audit opinion (MAO) dalam penelitian ini adalah opini audit selain opini wajar tanpa pengecualian bentuk baku, yaitu opini wajar tanpa pengecualian dengan paragraf penjelasan (unqualified opinion with explanatory paragraph), wajar dengan pengecualian (qualified opinion), tidak wajar (adverse opinion), dan tidak memberikan pendapat (disclaimer opinion). Terdapat tiga faktor yang memengaruhi probabilitas perusahaan mendapatkan modified audit opinion, yaitu kemungkinan salah saji yang substansial dalam laporan keuangan, kompetensi auditor, dan independensi auditor (Lin, Jiang, dan Xu 2011). Kemungkinan salah saji dapat dilihat dari keinginan perusahaan untuk meningkatkan laba, sedangkan faktor kompetensi dan independensi auditor mewakili kualitas audit. DeFond, Wong, dan Li (2000) menggunakan proporsi perusahaan yang menerima modified audit opinion sebagai proksi kualitas audit di Cina. Mereka berpendapat bahwa pengadopsian standar audit baru di Cina menyebabkan independensi auditor dan kualitas audit meningkat sehingga proporsi perusahaan yang mendapat modified audit opinion meningkat. Modified audit opinion dapat memberikan konsekuensi ekonomis bagi perusahaan yang mendapatkan opini tersebut, khususnya dalam hal keuangan atau perolehan pendanaan bagi perusahaan. Ketika perusahaan mengalami kesulitan dalam keuangan karena modified audit opinion yang diperoleh, hal ini menandakan bahwa perusahaan menghadapi financial constraint sebagai akibat dari didapatkannya modified audit opinion. Hal ini sejalan dengan hasil penelitian Gomez- Gillamon (2003) yang menemukan bahwa opini auditor memengaruhi keputusan lending dan investasi serta memengaruhi jumlah uang yang akan diberikan untuk investasi maupun loan. Lin, Tang, dan Xiao (2003) juga menemukan bahwa opini qualified berdampak negatif terhadap kredibilitas laporan keuangan, walau belum menemukan dampak signifikan dari pengaruh opini qualified terhadap investasi dan keputusan loan. Rendahnya konsekuensi ekonomis dari opini ini mungkin karena opini audit bukan merupakan informasi utama untuk penilaian kredit. Hal ini dibuktikan oleh hasil penelitian Omri, 
Errhili, dan Ghorbel (2011) yang menemukan bahwa opini audit menempati urutan keempat dalam penilaian kredit. Selain itu Omri, Errhili, dan Ghorbel (2011) juga menemukan bahwa laporan audit qualified berpengaruh negatif terhadap penilaian kredibilitas laporan keuangan dan keputusan pemberian kredit yang selanjutnya. Penelitian Lin et al. (2011) menemukan bahwa perusahaan yang mendapatkan modified audit opinion cenderung mendapatkan sedikit pinjaman dari bank karena bank ragu untuk memberikan pinjaman yang disebabkan laporan keuangan yang tidak mencerminkan kondisi keuangan yang sebenarnya. Selain itu Lin et al. (2011) menggunakan interaksi antara modified audit opinion dan operating cash flow dan melihat pengaruhnya terhadap pengeluaran investasi. Ketika perusahaan mendapatkan modified audit opinion, perusahaan akan menggunakan kas dari operating cash flow untuk mendanai investasi karena investor dan kreditor ragu untuk berinvestasi pada perusahaan akibat dari opini yang tidak bersih tersebut.

Opini audit yang berkualitas akan berdampak pada peningkatan kepercayaan pengguna laporan keuangan. Terutama bagi para investor sebagai dasar pengambilan keputusan. Serta bagi perusahaan yang tergabung dalam LQ45 adalah pihak perbankan dalam memberikan pinjaman dana.

Penelitian ini bertujuan untuk menginvestigasi apakah perusahaan yang mendapatkan modified audit opinion cenderung mudah atau sulit dalam mendapatkan pendanaan dari luar perusahaan. Secara khusus, penelitian ini akan menguji apakah modified audit opinion berpengaruh negatif terhadap pinjaman yang didapatkan perusahaan.

\section{KAJIAN PUSTAKA DAN PENGEMBANGAN HIPOTESIS}

Lambert et al. (2007) menyatakan bahwa rendahnya kualitas informasi akuntansi akan meningkatkan risiko estimasi investor dan agency cost sehingga investor meminta return yang lebih tinggi untuk mengimbangi risiko dan biaya 
yang meningkat. Lin et al. (2011) meneliti pengaruh modified audit opinion terhadap besarnya arus kas dari pinjaman (kemampuan perusahaan mendapat pinjaman). Hasil penelitiannya menemukan bahwa modified audit opinion berpengaruh negatif terhadap borrowing cash flow secara signifikan yang artinya perusahaan cenderung sulit untuk mendapatkan dana pinjaman dari pihak luar setelah perusahaan mendapatkan modified audit opinion. Oleh karena itu, hipotesis yang diajukan adalah:

H1: Semakin besar kemungkinan perusahaan mendapat modified audit opinion, maka semakin kecil kemungkinan perusahaan akan mendapatkan pinjaman dari pihak luar (borrowing cash flow). Pada penelitian ini juga akan diuji apakah jika perusahaan mendapat opini MAO dankebutuhan operating cash flow meningkat, apakah pinjaman dari luar perusahaan (bank dan perusahaan finansial lainnya) juga akan meningkat atau semakin turun. Pinjaman dari pihak luar bisa naik atau turun, pinjaman bank bisa naik karena kebutuhan dana perusahaan untuk membiayai $\mathrm{OCF}$, namun pinjaman luar juga bisa turun karena pihak luar tidak percaya kepada perusahaan sehubungan dengan opini MAO yang diperoleh perusahaan.Sehingga hipotesisnya adalah:

H2: Ketika perusahaan mendapat modified audit opinion, kebutuhan akan operating cash flow akan berpengaruh terhadap pinjaman dari pihak luar(borrowing cash flow).

\section{METODE PENELITIAN}

\section{Jenis dan Sumber Data}

Jenis penelitian dalam penelitian ini adalah jenis penelitian deskriptif dengan pendekatan kuantitatif, menjelaskan objek yang diteliti dengan cara memberikan deskripsi atau gambaran terhadap masalah yang telah didentifikasi dan dilakukan secara intensif dan terinci terhadap sektor pertmbangan di bursa efek Indonesia. Dengan cara menganalisis laporan keuangan. Penelitian ini menggunakan beberapa kriteria, yaitu: 
a. Tidak termasuk dalam kelompok perusahaan perbankan, sekuritas, asuransi atau lembaga keuangan lainnya karena perusahaan-perusahaan tersebut memiliki keterikatan regulasi pemerintah yang berbeda dari industri lainnya dan memberikan dana/modal kepada perusahaan lain.

b. Perusahaan dengan opini audit tidak tersedia.

c. Perusahaan publik yang memiliki data yang lengkap yang diperlukan dalam model penelitian.

d. Perusahaan publik yang mendapatkan pendapatan dari penjualan barang atau jasa yang ditawarkan dalam periode 2015-2017(sales tidak sama dengan nol).

\section{Definisi Operasional Variabel}

Langkah-langkah analisis data dalam penelitian ini adalah sebagai berikut:

Model Penelitian dan Pengukuran Variabel Terdapat dua model penelitian yaitu model a, Model a untuk menguji hipotesis 1 dan 2. Model a dibagi menjadi dua yaitu ketika MAO tidak dipecah (model 1a) dan ketika MAO dipecah (model 2a).

Model 1a

Model a digunakan untuk menguji hipotesis 1 dan 2. Untuk menguji hipotesis 1 digunakan model dari Sun et al. (2006), Yu and Pan (2008) dan Lin et al. (2011) sedangkan untuk menguji hipotesis 2 , pada model tersebut ditambahkan variabel interaksi antara MAO dan OCF.

Model 1a adalah:

BCFit $=\beta 0+\beta 1$ MAOit $+\beta 2$ ICFit $+\beta 3$ GROWTHit $+\beta 4$ ROAit $-1+\beta 5$ LEVit-1 $+\beta 6$ SIZEit + eit $\ldots . . .(1)$

Keterangan:

BCFit : Borrowing cash flow (kas pinjaman dari bank dan perusahaan finansial lainnya dibagi dengan saldo awal aset tetap) 
MAOit = opini audit dimana 1 jika opini audit tahun $\mathrm{t}-1$ adalah modified audit opinion dan 0 jika opini audit tahun t-1 adalah wajar tanpa pengecualian bentuk baku

ICFit : Investment cash flow (pembayaran kas untuk pembelian aset tetap, aset tidak berwujud, dan aset jangka panjang lainnya dibagi dengan saldo awal asset tetap)

GROWTHit : Pertumbuhan penjualan

ROAit-1 : Return on assets tahun $\mathrm{t}-1$

LEVit-1 : Financial leverage tahun $\mathrm{t}-1$

SIZEit : Ukuran perusahaan (log total aset)

Model 2a

Untuk mengetahui modified audit opinion mana yang berpengaruh signifikan pada model tersebut, maka modified audit opinion dibagi menjadi empat opini yaitu opini wajar tanpa pengecualian dengan paragraf penjelasan mengenai ketidakkonsistenan penggunaan prinsip akuntansi, going concern, dan terlibatnya auditor lain serta opini disclaimer. Opini wajar dengan pengecualian (qualified) dan tidak memberi pendapat (adverse) tidak dimasukkan dalam model karena tidak ada perusahaan di Indonesia yang mendapat opini tersebut untuk periode pengamatan 2010s.d. 2015. Dalam keputusan pemberian pinjaman kepada suatu perusahaan, pihak bank kemungkinan akan lebih memperhatikan opini wajar tanpa pengecualian dengan paragraf penjelasan mengenai going concern dan opini adverse. Sedangkan opini wajar tanpa pengecualian dengan paragraf penjelasan mengenai ketidakkonsistenan penggunaan prinsip akuntansi dan opini wajar tanpa pengecualian dengan paragraf penjelasan mengenai terlibatnya auditor lain mungkin tidak akan terlalu memengaruhi keputusan pemberian pinjaman oleh bank karena dalam memberikan pinjaman, bank akan lebih memerhatikan pada ketersediaan jaminan dan informasi privat lainnya. Maka model 2a adalah: 
BCFit $=\beta 0+\beta 1 \mathrm{UQAO} \_$CONSit-1 $+\beta 2 \mathrm{UQAO} \_$GOINGit $+\beta 3 \mathrm{UQAO} \_$AUDit + $\beta 4$ DISCit $+\beta 5$ ICFit $+\beta 6$ GROWTH it $+\beta$ ROAit $-1+\beta 8$ LEVit $-1+\beta 9$ SIZEit $+\varepsilon$ it (2)

Keterangan:

$\mathrm{BCF}=$ Borrowing cash flow

UQAO_CONSit-1 : Opini audit, dimana 1 jika opini audit tahun 1 adalah wajar tanpa pengecualian dengan paragraf penjelas, mengenai kurang konsistensinya penggunaan prinsip akuntansi dan 0 jika opini audit tahun $\mathrm{t} 1$ adalah lainnya.

UQAO_GOINGit : Opini audit, dimana 1 jika opini audit tahun 1 adalah wajar tanpa pengecualian dengan paragraf penjelas, mengenai going concern penggunaan prinsip akuntansi dan 0 jika opini audit tahun $\mathrm{t} 1$ adalah lainnya.

UQAO_AUDit : Opini audit, dimana 1 jika opini audit tahun 1 adalah tidak menyatakan pendapat, dan 0 jika opini audit tahun $\mathrm{t} 1$ adalah lainnya.

ICF it : Investment cash flow(pembayaran kas untuk pembelian aset tetap, aset tidak berwujud dan aset jangka penjang lainnya)

GROWTHit : Pertumbuhan penjualan(penjualan tahun $\mathrm{t}$ - penjualan tahun $\mathrm{t}-1$ )

Penjualan tahun t-1

ROAit-1 : Return on assets tahun $\mathrm{t}-1$

LEVit-1 : Financial leverage tahun $\mathrm{t}-1$

SIZEit : Ukuran perusahaan (log total aset)

Variabel dependen untuk model 1 dan 2 adalah borrowing cash flow dengan menggunakan rumus sebagai berikut:

$\mathrm{BCF}=($ arus kas borrowing - arus kas dari dan ke related party $)$

Beginning balance of total asset tahun ke $\mathrm{t}$

Variabel Kontrol Model 1a dan 2a 
Variabel kontrol yang digunakan untuk membantu menjelaskan hal-hal yang memengaruhi variabel borrowing cash flow adalah sebagai berikut:

\section{Controlling Shareholder}

Menurut Lin et al. (2011), ketika perusahaan menghadapi financial constraint, controlling shareholder akan membantu perusahaan dengan memberikan relatedparty loan.

Variabel controlling shareholder dalam penelitian ini merupakan variabel dummy dimana bernilai 1 jika perusahaan tidak memiliki controlling shareholder dan 0 jika perusahaan memiliki controlling shareholder. Variabel ini digunakan sebagai variabel kontrol yang mencerminkan efek soft budget dan untuk melihat apakah perusahaan yang memiliki controlling shareholder akan tetap meminjam dana dari bank dan perusahaan lainnya. Variabel ini diekspektasikan memiliki hubungan positif dengan borrowing cash flow karena perusahaan yang tidak memiliki controlling shareholder akan cenderung lebih banyak mendapatkan pinjaman dari bank dan perusahaan finansial lainnya. Dalam penelitian ini, variabel controlling shareholder diinteraksikan dengan operating cash flow untuk melihat apakah perusahaan yang tidak memiliki controlling shareholder akan lebih mengutamakan dana pinjaman bank dibandingkan dengan kas internal (operating cash flow) untuk menjalankan bisnisnya.

\section{Investment Cash Flow}

Variabel investment cash flow dalam model 1a dan 2a diekspektasikan memiliki hubungan positif dengan borrowing cash flow karena semakin besar pengeluaran investasi, maka dana yang dibutuhkan semakin banyak sehingga uang pinjaman yang dibutuhkan semakin meningkat (Lin et al. 2011).

\section{Growth}

Pertumbuhan (Growth) menjadi variabel kontrol dalam penelitian ini karena pertumbuhan perusahaan memengaruhi pinjaman yang dibutuhkan. Perusahaan yang sedang tumbuh membutuhkan dana pinjaman untuk pertumbuhan perusahaan. Semakin tinggi pertumbuhan penjualan perusahaan, maka semakin 
besar borrowing cash flow (Lin et al. 2011) karena skala usaha yang semakin besar membutuhkan dana untuk terus bertumbuh. Dana yang didapatkan digunakan untuk bertumbuh atau meningkatkan penjualan perusahaan. Dari pihak bank, mereka juga akan lebih cenderung memberikan pinjaman kepada perusahaan yang memiliki prospekpertumbuhan. Pertumbuhan diukur dari pertumbuhan penjualan.

\section{Return on Assets (ROA)}

Return on assets (ROA) mencerminkan kemampuan manajemen dalam memanfaatkan finansial dan investasi dalam bentuk aset untuk menghasilkan laba. Menurut Lin et al. (2011), semakin besar ROA, maka semakin besar dana pinjaman yang didapatkan perusahaan karena ROA yang lebih besar menandakan bahwa perusahaan dapat menghasilkan laba per aset yang lebih besar sehingga bank cenderung memberikan pinjaman. Dalam penelitian ini, ROA yang digunakan adalah ROA tahun t-1 karena bank dan perusahaan finansial lainnya melihat kinerja dari laporan keuangan tahun sebelumnya untuk membuat keputusan pinjaman.

\section{Leverage (LEV)}

Financial leverage merupakan tingkat dimana perusahaan bergantung pada utang. Semakin banyak perusahaan menggunakan utang dalam struktur modalnya, maka semakin besar financial leverage perusahaan. Semakin besar leverage perusahaan, maka semakin besar borrowing cash flow (Lin et al. 2011) karena ketika leverage perusahaan besar, kreditor beranggapan bahwa perusahaan bersifat agresif dalam menggunakan pembiayaan dengan utang yang dapat digunakan perusahaan untuk membiayai pertumbuhan perusahaan sehingga di masa depan perusahaan mampu menghasilkan keuntungan dan mampu membayar utang dan bunganya. Dalam penelitian ini, leverage yang digunakan adalah leverage tahun t-1 karena bank dan perusahaan finansial lainnya melihat kinerja dari laporan keuangan tahun sebelumnya untuk membuat keputusan pinjaman. 


\section{Ukuran Perusahaan (SIZE)}

Ukuran perusahaan diproksikan dengan log dari total year-end assets. Menurut Lin et al. (2011), semakin besar ukuran perusahaan, maka semakin besar borrowing cash flow. Hal ini berarti semakin besar perusahaan, dana pinjaman yang didapatkan perusahaan semakin besar karena perusahaan menggunakan dana pinjaman untuk berinvestasi dan mendanai pertumbuhan perusahaan.

Variabel dependen untuk model 1a dan 2a adalah borrowing cash flow. Borrowing cash flow ini mencakup dana pinjaman yang diterima dari bank dan pihak lain kecuali related party. Bisa dilihat aktivitas pendanaan jika mereka mendapatkan modified audit opinion. Borrowing cash flow dihitung dengan rumus:

$\mathrm{BCF}=$ (arus kas borrowing - arus kas dari dan ke related party) Beginning balance of total asset tahun tBorrowing cash flow di ambil dari laporan arus kas bagian arus kas dari aktivitas pendanaan (cash flow from financing activities).

\section{HASIL PENELITIAN DAN PEMBAHASAN}

\section{Statistik Deskriptif}

\section{Model 1}

Berdasarkan hasil olah data statistik deskriptif dapat diuraikan sebagai berikut:

1. Nilai borrowing cash flow/BCF dari perusahaan sampel pada tahun 2010 2015 rata rata 28,4125 . Hal ini berarti bcf pada perusahaan sampel tidak berpengaruh terhadap modified audit opinion, tingkat penjualan atau growth, size, roa dan lev.

2. Nilai modified audit opinion (MOA) dari perusahaan sampel pada tahun 2010 - 2015 rata - rata 0,5412. Hal ini berarti bahwa masih ada kinerja sampel yang tidak konsekuensi ekonomis bagi perusahaan yang mendapatkan opini tersebut, khususnya dalam hal keuangan atau pendanaan perusahaan. Ketika perusahaan mengalami kesulitan dalam keuangan, hal ini menandakan bahwa perusahaan mengahadapi financial constraint sebagai akibat dari didapatkannya 
modified audit opinion. Terdapat dua pandangan mengenai pengaruh modified audit opinion terhadap financial constraint perusahaan. Pandangan pertama adalah information asymmetry view. Ketika perusahaan mendapatkan modified audit opinion, maka dapat dikatakan bahwa kualitas informasi akuntansi perusahaan, dengan kata lain perusahaan yang memiliki perputaran pinjaman yang tinggi berdasarkan pada modified audit opinion baik.

3. Nilai kemampuan perusahaan dalam pertumbuhan penjualan (GROWTH) dari perusahaan sampel pada tahun 2010 - 2015 rata - rata 8,379. Rasio ini mengukur tingkat pertumbuhan pendapatan perusahaan setiap tahun. Hal ini berarti masih ada perusahaan sampel yang pertumbuhan pendapatan perusahaan tidak baik.

4. Nilai ukuran perusahaan (SIZE) rata - rata 15,1583 hal ini menunjukkan bahwa ada beberapa perusahaan sampel tidak mempergunakan variabel size sebagai pengukuran perusahaan terhadap borrowing cash flow atau tingkat pinjaman.

5. Nilai return on asset (ROA). Rasio ini menggambarkan tingkat pengembalian dari penggunaan aset yang menunjukkan profitabilitas perusahaan. kemampuan perusahaan sampel dalam menganalisis prosentase dari total pendapatan perusahaan yang dapat dikonversikan menjadi keuntungan atau laba perusahaan pada tahun 2010-2015 rata - rata 0,4435 hal ini berarti bahwa rata rata tingkat pengembalian aset perusahaan belum bisa mengukur tingkat pinjaman yang akan diberikan oleh pihak peminjam.

6. Nilai dana sendiri dengan dana pinjaman (LEV) pada perusahaan sampel selama tahun 2010- 2015 rata - rata 0,4609 hal ini berarti nilai leverage perusahaan sampel kurang begitu baik, akan tetapi belum tentu ekuitas berasal dari kinerjanya secara operasional, bisa juga dari non operasional, penjualan aset dan lain - lain. Sehingga bisa saja borrowing cash flow tidak berdasar pada tingkat leverage perusahaan sampel. 


\section{Model 2}

1. Nilai borrowing cash flow/BCF dari perusahaan sampel pada tahun 2010 2015 rata rata 13,7812. Hal ini berarti bcf pada perusahaan sampel tidak berpengaruh terhadap modified audit opinion, tingkat penjualan atau growth, size, roa dan lev.

2. Nilai investment cash flow (ICF) dari perusahaan sampel pada tahun 2010 - 2015 rata - rata 23,9243. Hal ini berarti bahwa masih ada kinerja sampel yang tidak konsekuensi ekonomis bagi perusahaan yang mendapatkan opini tersebut, khususnya dalam hal keuangan atau pendanaan perusahaan. Ketika perusahaan mengalami kesulitan dalam keuangan, hal ini menandakan bahwa perusahaan mengahadapi financial constraint sebagai akibat dari didapatkannya modified audit opinion. Terdapat dua pandangan mengenai pengaruh modified audit opinion terhadap financial constraint perusahaan. Pandangan pertama adalah information asymmetry view. Ketika perusahaan mendapatkan modified audit opinion, maka dapat dikatakan bahwa kualitas informasi akuntansi perusahaan, dengan kata lain perusahaan yang memiliki perputaran pinjaman yang tinggi berdasarkan pada modified audit opinion baik.

3. Nilai kemampuan perusahaan dalam pertumbuhan penjualan (GROWTH) dari perusahaan sampel pada tahun 2010 - 2015 rata - rata 77.8425. Rasio ini mengukur tingkat pertumbuhan pendapatan perusahaan setiap tahun. Hal ini berarti masih ada perusahaan sampel yang pertumbuhan pendapatan perusahaan tidak baik.

4. Nilai ukuran perusahaan (SIZE) rata - rata 15,0164 hal ini menunjukkan bahwa ada beberapa perusahaan sampel tidak mempergunakan variabel size sebagai pengukuran perusahaan terhadap borrowing cash flow atau tingkat pinjaman.

5. Nilai return on asset (ROA). Rasio ini menggambarkan tingkat pengembalian dari penggunaan aset yang menunjukkan profitabilitas perusahaan. kemampuan perusahaan sampel dalam menganalisis prosentase dari total pendapatan perusahaan yang dapat dikonversikan menjadi keuntungan atau laba 
perusahaan pada tahun 2010-2015 rata - rata 0,4435 hal ini berarti bahwa rata rata tingkat pengembalian aset perusahaan belum bisa mengukur tingkat pinjaman yang akan diberikan oleh pihak peminjam.

6. Nilai dana sendiri dengan dana pinjaman (LEV) pada perusahaan sampel selama tahun 2010- 2015 rata - rata 0,4609 hal ini berarti nilai leverage perusahaan sampel kurang begitu baik, akan tetapi belum tentu ekuitas berasal dari kinerjanya secara operasional, bisa juga dari non operasional, penjualan aset dan lain - lain. Sehingga bisa saja borrowing cash flow tidak berdasar pada tingkat leverage perusahaan sampel.

\section{Uji Asumsi Klasik}

Hasil pengujian hipotesis yang baik adalah pengujian yang tidak melanggar asumsi klasik yang mendasari model regresi linier berganda. Asumsi klasik dalam penelitian ini meliputi uji normalitas, uji multikolonieritas, uji autokorelasi, dan uji heterokedasitas. Pengujian - pengujian model 1 dan model 2 tersebut dapat diuraikan sebagai berikut:

\section{Uji Normalitas}

Pola distribusi adalah normal karena data mengikuti arah garis grafik histogramnya. Normal probability plot menunjukkan bahwa data menyebar di sekitar garis diagonal dan mengikuti arah garis diagonal, serta menunjukkan pola distribusi normal, sehingga dapat disimpulkan bahwa asumsi normalitas telah terpenuhi.

\section{Uji Multikolonieritas}

Berdasarkan aturanVIF (variance influence factor) dan tolerence, maka apabila VIF melebihi angka 10 atau Tolerence kurang dari0,10, maka dinyatakan terjadi gejala multikolonieritas, sebaliknya apabila harga VIF kurang dari 10 atau tolerence lebih dari,0,10, maka dinyatakn tidak terjadi gejala multikolonieritas. Uji multikolonieritas sebagai berikut: 
Semua variabel independen memiliki nilai tolerence berada dibawah 1 dan nilai VIF jauh dibawah 10. Dengan demikian dapat dikatakan bahwa model yang terbentuk tidak memiliki gejala multikolonieritas.

\section{Uji heteroskedasitas}

Hasil pengujian mengindikasikan tidak ada satupun variabel independen yang signifikan secara statistik mempengaruhi nilai residual absolut. Hal ini berarti probabilitas signifikansinya di atas kepercayaan 5\% untuk BCF model 1 sebesar 0,78 dan BCF model 2 sebsesar 0,59. Jadi dapat disimpulkan bahwa tidak ada indikasi heteroskedasitas nilai residual persamaan dengan variabel independen penelitian.

\section{Uji Autokorelasi}

Hasil regresi dengan level signifikansi $0,05(\alpha=0,05)$ dengan jumlah variabel independen $(\mathrm{k}=1)$ dan banyaknya data $(\mathrm{N}=240)$, didapat nilai DW hitung sebesar 0,653 sedangkan besarnya dU/df1 (batas atas) $=4$. Oleh karena DW hitung lebih besar dari batas atas (dU) maka dapat disimpulkan bahwa tidak terjadi problem autokorelasi.

\section{Koefisien Determinasi}

Koefisien determinasi digunakan untuk melihat bagaimana variabel independen dapat menjelaskan variabel dependen. Dari tabel 4.5 dapat diketahui besarnya nilai koefisien determinasi model 1 sebesar 0,203. Hal ini dapat diartikan bahwa BCF dijelaskan dari variasi rasio keuangan dan MOA sebesar 20,3 persen. Sisanya 79,7 persen dijelaskan oleh sebab lain diluar model yang tidak dimasukkan dalam penelitian. Dari tabel 4.5 dapat diketahui besarnya nilai koefisien determinasi model 2 sebesar 0,176. Hal ini dapat diartikan bahwa BCF dijelaskan dari variasi rasio keuangan dan MOA sebesar 17,6 persen. Sisanya 83,4 persen dijelaskan oleh sebab lain diluar model yang tidak dimasukkan dalam penelitian. 


\section{Uji F}

Nilai F hitung sebesar 2,007 dengan tingkat signifikansi 0,001 dan lebih kecil dari 0,05, maka model regresi dapat digunakan untuk memprediksi kinerja borrowing cash flow perusahaan. Dengan kata lain Rasio keuangan, growth, size dan Moa (bersama - sama) berpengaruh terhadap BCF.

Dari hasil uji mengatakan nilai $\mathrm{F}$ hitung sebesar 0,821 dengan tingkat signifikansi 0,001 dan lebih kecil dari 0,05, maka model regresi dapat digunakan untuk memprediksi kinerja borrowing cash flow perusahaan. Dengan kata lain Rasio keuangan, growth, ICF, size dan Moa (bersama - sama) berpengaruh terhadap BCF.

\section{Uji t (Uji parsial)}

Persamaan regresi model 1 sebagai berikut :

BCFit $=\beta 0+\beta 1$ MAOit $+\beta 2$ GROWTHit $+\beta 3$ ROAit $-1+\beta 4$ LEVit $-1+\beta 5$ SIZEit + cit ....... (1)

Keterangan:

BCFit : Borrowing cash flow (kas pinjaman dari bank dan perusahaan finansial lainnya dibagi dengan saldo awal aset tetap)

MAOit = opini audit dimana 1 jika opini audit tahun $\mathrm{t}-1$ adalah modified audit opinion dan 0 jika opini audit tahun t-1 adalah wajar tanpa pengecualian bentuk baku

GROWTHit : Pertumbuhan penjualan

ROAit-1 : Return on assets tahun $\mathrm{t}-1$

LEVit-1 : Financial leverage tahun $\mathrm{t}-1$

SIZEit : Ukuran perusahaan (log total aset) 


\section{UJI t}

Model 1

Variabel MOA berpengaruh negatif tetapi tidak signifikan terhadap BCF, variabel Growth berpengaruh positif tetapi signifikan terhadap BCF, variabel ROA berpengaruh negatif tetapi tidak signifikan terhadap $\mathrm{BCF}$, variabel LEV berpengaruh negatif tetapi tidak signifikan terhadap BCF. Variabel Size berpengaruh negatif tetapi tidak signifikan terhadap BCF. Growth yang berpengaruh positif menunjukkan bahwa kenaikan penjualan menyebabkan perusahaan melakukan BCF karena adanya ketersediaan pendapatan yang baik pada periode mendatang.

a. Pengaruh modified audit opinion terhadap kemampuan perusahaan untuk memperoleh pinjaman.

Tabel 1 kolom 4 menunjukkan bahwa modified audit opinion memiliki Prob t sebesar 0,002 untuk model 1a yang berarti modified audit opinion tidak mempengaruhi borrowing cash flow secara signifikan karena nilai tersebut lebih besar dari $\alpha$ 5\%. Hal ini sejalan dengan temuan Lin et al. (2011) yang menunjukkan bahwa modified audit opinion tidak mempengaruhi borrowing cash flow secara signifikan dari tahun 1998 hingga tahun 2004 (kecuali tahun 2003).

Hasil ini mungkin terjadi karena laporan audit bukanlah satu-satunya pertimbangan bagi bank dan perusahaan finansial lainnya untuk memberikan pinjaman. Menurut panduan pemberian pinjaman dari salah satu bank di Indonesia, terdapat lima pertimbangan yang dinilai untuk memberikan kredit, yaitu character, capacity, capital, conditions, dan collateral. Bank dalam menilai risiko kredit perusahaan juga melihat itikad, integritas, dan kejujuran dari pemimpin perusahaan (character). Capacity dan capital dilihat dari laporan keuangan yang telah diaudit. Bank juga menilai variabel eksternal untuk lingkungan bisnisnya (conditions). Selain itu, bank juga melihat aset apa saja yang dapat dijadikan jaminan ketika debitur gagal bayar. 
Temuan ini juga didukung oleh hasil temuan Omri, Errhili, dan Ghorbel (2011) yang menyatakan bahwa opini audit menempati urutan keempat sebagai sumber informasi untuk memberikan kredit bagi bank di Tunisia. Informasi yang dinilai berasal dari laporan keuangan, informasi dari Bank Sentral Tunisia, dan hubungan (relasi) antara bank dan perusahaan. Setelah itu bank baru mempertimbangkan opini audit.

\section{Model 2}

Untuk mengetahui modified audit opinion mana yang berpengaruh signifikan pada model tersebut, maka modified audit opinion dibagi menjadi empat opini yaitu opini wajar tanpa pengecualian dengan paragraf penjelasan mengenai ketidakkonsistenan penggunaan prinsip akuntansi, going concern, dan terlibatnya auditor lain serta opini disclaimer. Opini wajar dengan pengecualian (qualified) dan tidak memberi pendapat (adverse) tidak dimasukkan dalam model karena tidak ada perusahaan di Indonesia yang mendapat opini tersebut untuk periode pengamatan 2010 sampai 2015. Dalam keputusan pemberian pinjaman kepada suatu perusahaan, pihak bank kemungkinan akan lebih memperhatikan opini wajar tanpa pengecualian dengan paragraf penjelasan mengenai going concern dan opini adverse. Sedangkan opini wajar tanpa pengecualian dengan paragraf penjelasan mengenai ketidakkonsistenan penggunaan prinsip akuntansi dan opini wajar tanpa pengecualian dengan paragraf penjelasan mengenai terlibatnya auditor lain mungkin tidak akan terlalu memengaruhi keputusan pemberian pinjaman oleh bank karena dalam memberikan pinjaman, bank akan lebih memerhatikan pada ketersediaan jaminan dan informasi privat lainnya. Maka model 2a adalah:

BCFit $=\beta 0+\beta 1 \mathrm{UQAO} \_$CONSit-1 $+\beta 2 \mathrm{UQAO} \_$GOINGit $+\beta 3 \mathrm{UQAO} \_$AUDit + $\beta 4$ DISCit $+\beta 5$ ICFit $+\beta 6$ GROWTH it $+\beta$ ROAit $-1+\beta 8$ LEVit-1 $+\beta 9$ SIZEit $+\varepsilon$ it 
Keterangan:

$\mathrm{BCF}=$ Borrowing cash flow

UQAO_CONSit-1 : Opini audit, dimana 1 jika opini audit tahun 1 adalah wajar tanpa pengecualian dengan paragraf penjelas, mengenai kurang konsistensinya penggunaan prinsip akuntansi dan 0 jika opini audit tahun t1 adalah lainnya.

UQAO_GOINGit : Opini audit, dimana 1 jika opini audit tahun 1 adalah wajar tanpa pengecualian dengan paragraf penjelas, mengenai going concern penggunaan prinsip akuntansi dan 0 jika opini audit tahun $\mathrm{t} 1$ adalah lainnya.

UQAO_AUDit : Opini audit, dimana 1 jika opini audit tahun 1 adalah tidak menyatakan pendapat, dan 0 jika opini audit tahun $\mathrm{t} 1$ adalah lainnya.

ICF it : Investment cash flow(pembayaran kas untuk pembelian aset tetap, aset tidak berwujud dan aset jangka penjang lainnya)

GROWTHit : Pertumbuhan penjualan(penjualan tahun $\mathrm{t}$ - penjualan tahun $\mathrm{t}-1$ ) Penjualan tahun $\mathrm{t}-1$

ROAit-1 : Return on assets tahun $\mathrm{t}-1$

LEVit-1 : Financial leverage tahun $\mathrm{t}-1$

SIZEit : Ukuran perusahaan (log total aset)

Tabel model 2 menunjukkan bahwa hanya opini wajar tanpa pengecualian dengan paragraf penjelasan mengenai going concern yang mempengaruhi borrowing cash flow. Hal ini berarti hanya opini wajar tanpa pengecualian dengan paragraf penjelasan mengenai going concern yang mempengaruhi keputusan pemberian pinjaman oleh kreditor. Tanda koefisien negatif yang menandakan bahwa ketika perusahaan mendapatkan opini wajar tanpa pengecualian dengan paragraf penjelasan mengenai going concern, maka perusahaan tersebut 
cenderung mendapatkan pinjaman yang lebih sedikit dibandingkan dengan perusahaan yang mendapatkan opini lainnya.

Variabel kontrol untuk model 1a dan 2a adalah pengeluaran investasi, pertumbuhan penjualan, return on asset, leverage, dan ukuran perusahaan. pengeluaran investasi tidak berpengaruh signifikan dan positif terhadap borrowing cash flow. Pengeluaran investasi (growth) berpengaruh signifikan dan positif terhadap borrowing cash flow. Return on asset tidak berpengaruh terhadap keputusan kreditor dalam memberikan pinjaman. Leverage tidak mempengaruhi borrowing cash flow secara signikan dan positif. Ukuran perusahaan tidak mempengaruhi keputusan kreditor dalam memberikan pinjaman.

b. Pengaruh modified audit opinion terhadap kemampuan perusahaan untuk berinvestasi

Hal ini terjadi karena opini yang didapatkan perusahaan tidak menentukan apakah perusahaan akan lebih banyak atau sedikit dalam membeli aset. Namun, jika opini tersebut mempengaruhi pendanaan dari luar perusahaan, maka akan berpengaruh terhadap pengeluaran investasi perusahaan. Dari model 1 terlihat bahwa opini audit tidak mempengaruhi borrowing cash flow sehingga dapat dikatakan bahwa perusahaan masih mungkin mendapatkan pinjaman dari bank walaupun mendapatkan opini yang tidak bersih. Selain itu, temuan sebelumnya mengindikasikan bahwa perusahaan yang mendapatkan modified audit opinion akan menggunakan kas internal (operating cash flow untuk membiayai pembelian aset. Perusahaan juga mungkin mendapatkan bantuan dari controlling shareholder dan pihak yang memiliki hubungan istimewa. Oleh karena itu, modified audit opinion yang didapat tidak mempengaruhi besarnya pengeluaran investasi. 


\section{Pengujian Hipotesis}

1.Pengujian Hipotesis 1: H1: Semakin besar kemungkinan perusahaan mendapat modified audit opinion, maka semakin kecil kemungkinan perusahaan akan mendapatkan pinjaman dari pihak luar (borrowing cash flow).

Dari hasil penelitian nilai koefisien transformasi untuk regresi untuk variabel MAO tidak berpengaruh positif terhadap BCF. Dengan angka sebear -0,271 dengan signifikansi 0,787. Hanya variabel kontrol Growth yang berpengaruh secara signifikan terhadap BCF sebesar 0,063 tetapi tidak signifikan. Berarti Hipothesis pertama tidak diterima.

2.Pengujian Hipotesis 2: Ketika perusahaan mendapat modified audit opinion, kebutuhan akan operating cash flow akan berpengaruh terhadap pinjaman dari pihak luar(borrowing cash flow).

Hipothesis kedua menunjukkan bahwa MAO akan berpengaruh terhadap BCF juga tidak berpengaruh secara positif. Demikian pula variabel ICF tidak berpengaruh positif terhadap BCF. Hipothesis kedua tidak diterima.

Berdasarkan hasil analisis statistik deskriptif karakteristik sampel yang digunakan didalam penelitian ini meliputi jumlah sampel $(\mathrm{N})$, rata - rata sampel (Mean), nilai minimum, nilai maksimum, dan standar deviasi untuk masing - masing variabel yaitu sebagai berikut:

\section{PENUTUP}

\section{Simpulan}

Penelitian ini bertujuan untuk melihat konsekuensi ekonomis dari modified audit opinion yang diperoleh perusahaan terhadap tingkat borrowing cash flow dan pengeluaran investasi perusahaan tersebut. Modified audit opinion dalam penelitian ini dibagi menjadi empat opini, yaitu wajar tanpa pengecualian dengan paragraf penjelasan mengenai kurang konsistennya penggunaan prinsip akuntansi, going concern, dan terlibatnya auditor lain serta opini disclaimer. Sampel 
penelitian ini adalah 40 perusahaan publik selain institusi keuangan yang tercatat di LQ 45 dengan periode observasi dari tahun 2010 sampai 2015. Dari hasil pengujian dan analisis hasil penelitian didapatkan kesimpulan sebagai berikut:

a. Modified audit opinion yang diperoleh perusahaan tidak terbukti mempengaruhi kemampuan perusahaan mendapatkan pinjaman. Hal ini berarti opini audit tidak mempengaruhi keputusan kreditor untuk memberikan pinjaman. Namun, dari semua jenis modified audit opinion, hanya opini wajar tanpa pengecualian dengan paragraf penjelasan mengenai going concern yang mempengaruhi keputusan kreditor dalam memberikan pinjaman secara negatif. Hal ini berarti perusahaan yang mendapatkan opini wajar tanpa pengecualian dengan paragraf penjelasan mengenai going concern akan memperoleh pinjaman yang lebih sedikit dibandingkan dengan perusahaan yang mendapatkan opini lainnya. b. Perusahaan yang mendapatkan modified audit opinion terbukti menggunakan lebih banyak kas internal (operating cash flow) untuk membiayai pembelian aset dibandingkan dengan perusahaan yang mendapatkan opini wajar tanpa pengecualian bentuk baku. Modified audit opinion tersebut adalah wajar tanpa pengecualian dengan paragraf penjelasan mengenai kurang konsistennya penggunaan prinsip akuntansi dan going concern. Hal ini menandakan bahwa perusahaan yang mendapatkan modified audit opinion, khususnya opini wajar tanpa pengecualian dengan paragraf penjelasan mengenai kurang konsistennya penggunaan prinsip akuntansi dan going concern, menghadapi financial constraint dan efek informasi asimetri lebih besar dibandingkan dengan efek soft budget.

Pertumbuhan penjualan terbukti mempengaruhi pengeluaran investasi dan borrowing cash flow secara positif dan signifikan. Hal ini diduga karena perusahaan terlihat semakin bertumbuh sehingga kreditor percaya bahwa perusahaan dapat membayar pokok utang beserta bunganya di masa depan. Ukuran perusahaan tidak terbukti mempengaruhi pengeluaran investasi untuk model $1 b$. Namun, hasil ini tidak konsisten untuk model $2 b$ yang menunjukkan bahwa ukuran perusahaan terbukti mempengaruhi pengeluaran investasi secara negatif dan signifikan. Ukuran perusahaan terbukti berpengaruh positif dan signifikan terhadap borrowing cash flow perusahaan. Perusahaan yang memiliki total aset yang besar akan cenderung mendapatkan pinjaman lebih besar karena 
mereka memiliki aset yang besar yang dapat digunakan sebagai jaminan bagi kreditor.

Leverage memberikan cukup bukti bahwa perusahaan di Indonesia yang memiliki leverage besar akan mendapatkan kas pinjaman yang lebih besar dibandingkan dengan yang memiliki leverage kecil. Hal ini diduga karena rasio leverage yang tinggi menunjukkan sifat agresif perusahaan dalam menggunakan pembiayaan dengan utang dan kreditor berekspektasi perusahaan mampu menghasilkan keuntungan di masa depan dari hasil penggunaan utang untuk pertumbuhan perusahaan. Pengeluaran investasi terbukti berpengaruh negatif dan signifikan terhadap borrowing cash flow. Hal ini diduga karena perusahaan menggunakan kas internal untuk belanja aset dan menunjukkan bahwa tidak mudah mendapatkan pinjaman dari bank dan perusahaan finansial lainnya yang digunakan untuk membeli aset, khususnya aset tidak lancar.

\section{Keterbatasan Penelitian dan Saran}

Adapun beberapa keterbatasan dalam penelitian ini menyangkut beberapa hal:

1. Pada jangka waktu penelitian yang hanya mengambil periode observasi selama 5 tahun karena keterbatasan waktu penelitian. Disarankan kepada penelitian selanjutnya untuk menambah jangka waktu penelitian agar semakin banyak data perusahaan yang dapat dijadikan sampel sehingga data semakin valid. 2. Pengambilan sampel dari jenis-jenis industri yang menghasilkan produk yang berbeda sehingga mungkinmenimbulkan perbedaan risiko industri yang dipertimbangkan oleh kreditor dalam memberikan pinjaman.

3. Pada penelitian sebelumnya, digunakan variabel koneksi politik yang diwakili oleh kepemilikan pemerintah yang mewakili efek soft budget. Dalam penelitian ini, sampel yang digunakan hanya lah perusahaan yang memiliki kepemilikan saham terbesarnya sebesar 50\% (memiliki controlling shareholder) untuk mewakili efek soft budget sehingga kurang menjelaskan efek soft budget itu sendiri. Disarankan kepada penelitian selanjutnya jika ingin menggunakan variabel koneksi politik sebagai cerminan dari soft budget view, maka perlu dilakukan penelitian terlebih dahulu terkait keberadaan hubungan politik pada perusahaan publik di Indonesia agar penelitian semakin valid. 


\section{DAFTAR PUSTAKA}

Arens, Alvin A., R. J. Elder, dan M. S. Beasley. (2012). Auditing and Assurance Services: An Integrated Approach,14ed: Pearson Prentice Hall

Fazzari, S. M. et al. 1988. Financing Constraints and Corporate Investment. Brookings Paper on Economic Activity, 1, 141-206.

Guillamon, G., A. Durendez. 2003. The Usefulness of the Audit Report in Investment and Financing Decisions. Managerial Auditing Journal, 18, 549- 559.

Hardina P, Fitriani (2013) PENGARUH MODIFIED AUDIT OPINION TERHADAP BORROWING CASH FLOW DAN INVESTMENT CASH FLOW , Jurnal Akuntansi dan Keuangan Indonesia Volume 10 Nomor 1, Juni 2013

Kurnia yulius (2009), faktor - faktor yang mempengaruhi penerimaan opini audit going concern pada perusahaan publik sektor manufaktur, jurnal bisinis dan akuntansi vol. 11 no.3 Desember 2009

Lin, Z. et al. 2003. An Experimental Study of Users' Responses to Qualified Audit Reports in China. Journal of International Accounting, Auditing \& Taxation, 12, 1-22.

Lin, Z., Y. Jiang, dan Y. Xu. 2011. Do Modified Audit Opinions Have Economic Consequences? Empirical Evidence Based on Financial Constraints. China Journal of Accounting Research, 4, 135-154. 